\title{
What Say the Human Wisdom, the Philosophy and Culture and What Says the Bible on the Sense of the Human Life, on its Destination
}

\section{Olkhovsky V $\mathbf{S}^{1,2^{\star}}$}

${ }^{1}$ Institute for Nuclear Research of NASU, prospekt Nauki, 47, Kiev-03028, Ukraine

${ }^{2}$ Institute of the life and Universe Genesis in the Ukraine, Kiev, Ukraine

*Corresponding author: Olkhovsky VS, Institute of the life and Universe Genesis in the Ukraine, Kiev, Ukraine, Tel: 03-9762-8333; E-mail: olkhovsky@mail.ru

Rec date: Feb 04, 2014, Acc date: Jul 09, 2014, Pub date: Jul 16, 2014

Copyright: (c) 2014 Olkhovsky VS. This is an open-access article distributed under the terms of the Creative Commons Attribution License, which permits unrestricted use, distribution, and reproduction in any medium, provided the original author and source are credited.

\begin{abstract}
This Christian philosophical paper analyses the sense of human life. The problem of the life sense many thinkers of the past had been tried to solve for a long time. It is in the center of the attention of the modern philosophy. However the mono-semantic answer to the question about the life sense in the human philosophy does not exist. Various philosophers and thinkers include in the notion of the life sense different contents. And there are only Christian men and women who found the life, full up of the sense. They began from that, that for them the sense of human life is absurd to seek in themselves, in the dark, senseless life of the everyday experience. They found the life intelligent, or, that is the same, obtained the Alive Sense, accepted Christ and went with him.
\end{abstract}

Keywords: The sense of the human life; Philosophy; Christ; Bible

\section{Introduction}

What is the sense of the life for any separated man? This question not only pedagogues, philosophers and theologians pose, but at all it troubles many men and women, beginning from the childhood. And is it possible to educate the growing generation, consistently, internally non-contradictory, in families, in the child and educational institutions, if the question on the life sense is not in principle resolved by the educators, teachers and instructors?

It is natural firstly to bring the question on the life sense onto the question about the human destination in our world - for what a man lives on the earth?

If one poses such questions to any by-passer (more or less educated), then it is possible to obtain at least four various relations to these questions:

One can say that, not knowing the answers to these questions, people in their life are similar to a man which began to play some joke, knowing neither sense, nor its rules.

Another can say that this topic is too far from the real life of any man.

The third one - this topic is so important that touches the interests of any man.

And the fourth one can say that firstly we would clear up the question about what is the truth and if a man can it find, and then already ask: for what a man lives!

In 1856 the known Russian surgeon and pedagogue Pirogov NI in his article "The questions of life" wrote [1] that many people do not even think on the sense of their existing and, nevertheless, consider themselves happy and satisfied by their life. And the cause of that is in the following: someone from them "obtained from the nature the pitiable privilege for the idiotism", and others simply live over the inertia, non-thinking particularly about anything. And his conclusion was: of course, neither the firsts, nor neither the seconds it is impossible to include in the list of persons which lead actually the human image of life. It is typical for a man to have seeking; the troubling seeking's of the aim of his existing.

The French philosopher and writer A Camu in his essay "the myth on Sizife" wrote [2], that it is only one fundamental philosophical question. It is the question about that, if the life is worth or it is not worth in order to live. All other questions are secondary. Therefore "the question about the life sense I consider the most urgent from all the questions" - he concludes.

The problem of the life sense many thinkers of the past had been tried to solve. It is in the center of the attention of the modern philosophy. However the mono-semantic answer to the question about the life sense in the human philosophy does not exist. Various philosophers and thinkers include in the notion of the life sense different contents:

The firsts of them denies it, considering that there is no the life sense ("vanity of vanities"). It was originated in one of the ancient conceptions in the book of Ecclesiastes $(\sim 10 \mathrm{sec}$. before Christ). In it the nothingness and vanity of the human life is underlined. $\mathrm{He}$ assumes that also the addends of the life - wealth, power, love and work - are so the senseless, as the pursuit over the wind. All this is "vanity of vanities, - all is vanity", "all is vanity and vexation of spirit". Such pessimistic conclusion was made by Ecclesiast because, that one fate grasps the everybody: "the wise man dieth as the fool" (Eccles., 2:16), and "All things come alike to all: there is one event to the righteous, and to the wicked; to the good and to the clean, and to the unclean; to him that sacrificeth, and to him that sacrificeth not: as is the good, so is the sinner..."(Eccles., 9:2).

In fact, also Ecclesiast denied the human sense of life but only for a man himself and acting in the context of only himself. The world is really in the evil, is deeply sinked in the bog of the sin and untruth. And for someone, who does nothing see, besides this dark side of the reality, to him becomes comprehensive all this "the world sorrow", 
beginning from Solomon ("vanity of vanities and all is vanity and vexation of spirit", "he that increseth knowledge increseth sorrow") and finishing by the modern pessimists. We note that all this relates not to all book but only to the part of the book of Ecclesiast.

The seconds of them although recognize it, but include in this sense to it all negative (for instance, "sorrow"). The desolate estimation of the life was given by the Indian thinker Buddha as early as 6 centuries before the Christmas. He lived in Re chambers among the luxury and comfort. But one day he went out the palace walls and saw the life in its mean view: he met the ill man, then the decrepit old man and finally the dead body which was carried to bury. And he made conclusion that in this life the illness, old age and death dominate, in it the sorrow dominates. And sorrow originates from the desire which finally cannot be satisfied. Therefore he decided: it is necessary to exterminate inside him the desire, to annihilate inside his the personality by the ascetic exercises, dissolve him in the impersonal "nirvana". Buddha was right relative to his environment: this world is situated in the evil, as the apostle John witnessed. Buddha knew only the mean reality of "the world of phenomena", and therefore his pessimism is comprehendable. He observed only this "light" which turned out really by the kingdom of the darkness.

And the German philosopher Shopengauer, the author of the book "The world as the will and representation" [3], names the life as a pendulum between the suffering and the boredom. "The need is a whip for the simple men, the boredom is a whip for the nobility". A man with his desires is "eternally pining Tantal". According the Greek legend, he is punished in the hell by torments of the dissatisfaction: when he is inclined to the water in order to drink, the water goes away from him; when he extends his hand to the fruits which hang on the tree, the branch removes from him. The suffering gives birth the wishing in a man but the wishing again brings the suffering. However the absence of the sufferings brings still larger disaster: it gives birth of the killing sorrow, the emptiness.

The thirds of them recognize the sense of life, implying something "positive" ("happiness", "moral", "future - children, humanity, communism" etc.). They also are divided on the groups:

Some (1) say to us that the sense of life is in the pleasure. So the supporters of the gedonism study (from the Greek word "gedone" "pleasure"). "We shall eat and drink because to-morrow we shall die!" But where the proofs that we shall die and we shall not live after the death? Our thoughts, mind, consciousness, internal feeling (intuition) confirm the biblical revelation on the immortality and on the eternity. It says to us: remember that you die. And it warns: remember that you will live, exist after the death.

Others (2) (the supporters of the eudemonism) say to us that the sense of life is good (from the Greek word "eudemoniya" - happiness, welfare). But in what is it? Where is such good which would satisfy all the human needs?

Still others (3) (the supporters of the utilitarism) see the sense of life in the obtaining the use (from the Latin word "utilis" - "useful"). But in what is this use - absolute, eternal, to everybody accessible?

And those (4), who assume that the sense in our "future", put in fact the answer to the question on the sense of life to the shoulders of the future generations!

There are also such persons (5), which consider even that the sense of life is simple in it itself. But this is both to go away from the answer, and at the same time the senseless thing: what does mean live for transient life?

Not only the various authors understand it in different ways but even the same authors (for instance, Tolstoy L, Freud $Z, \ldots$ ) express formulations which are badly consistent with each other.

The supporters of the materialism, which recognize only the visible, tangible matter and reject the primarity of the spirit and the eternity, bring us to the dead end, to the blank wall of the despair, hopelessness and aimlessness. And moreover, created by the men philosophies and ideologies (including not only paganism but also buddhism and other east philosophies with the typical doctrine of the reincarnations of the soul of every man after death, and also the ideologies where there are the kismet [fate] and the double predestination of men independently from their will (some are predestinated to the paradise and some - to the hell) finally bring to the same result.

And although in any theory there is a certain part of the reality, truth, these answers do not satisfy us (because something more essential is evidently absent in them!).

If we go away from these ideologies, theories, wise thoughts and abstract philosophies and see only on the practical behavior of people which sought or now seek the sense of life, then we can see the following $\rightarrow$

\section{Practically it is possible to divide such men for four groups [4]:}

Some, tired in the fruitless search and lost the desire to the further search, cast down the hands. They try not to think on this "cursed question". Their single desire is to go away from the annoying insoluble thought, seeking oblivion. They as if, according the French poet-lyric Bodler, were "wigging out". They are wigging out also in the direct, physical sense - by alcool. They are wigging out ourselves by the nicotine (in the smoking), by the opium, morphia, which help them even though for some time to go from the everyday, dull, miserable life. They go away in the world of the fantasy, wig out in the art, theater and cinema, sometimes in the religion extasy. They are reading a lot of books; go away in some affair, non-giving themselves any respite, in order that again the troubly, tormenting question does not pose: why? for what?

These men fear not the eight hours of the everyday work but the remained sixteen hours of the leisure when they can remain with themselves and again appear with the same obtrusive questions: For what all this? To where I go? Why I live?

And a man seeks the new and again the new ways of oblivion, selfoblivion. But just in a certain time the artificial jimson weed will finished and the great awakening, revalutation will become. And what then?

The men of the second category are those, who remake their life by the external methods-with the help of the peaceful reforms or the violation means, by the evolutions and revolutions, rebellions. They do not see the sense in the life which it is, and they tend to prescribe, to attach and even to obtrude to it their invented and sometimes he reasonable sense. But alas! With all these influences, impacts and revolutions, demanding the huge expense of the energy, large currents of the blood and tears, the mean reality is not in fact changed. And such makers and re-makers must find themselves before the life intelligent, overcoming the illness, sin and death, and only after to transform the reality and construct a new, true life: "Doctor, heal himself, before to heal others!'” 
On these external rebellions the wise author of the book of Ecclesiast would say the same, as earlier, verdict: "vanity of vanities, vanity and vexation of spirit", "there is no new thing under the sun", and that superficially seems to be new finally appears the old sad truth, only narrated by other words.

To the third group the people are related which, despaired in the search of the true sense of the life, do away from the life. Someone goes externally, trying with self-violation to interrupt the thread of life. Other one goes internally, goes inside himself, isolating "in box". Such men leave the people and retire in loneliness.

And now once more we see to the Bible, again beginning from the book of Ecclesiast:

Besides words "vanity of vanities, all is vanity and vexation of spirit" there are in the book of Ecclesiast also such practical instructions for men: if the death of a man is inevitable, then it is remained to use in the best way possible a short term of life, released to us. In this case, according to Ecclesiast, either the wisdom, or the creative work, or the love, and the wealth obtain the positive value, because this is the gift of God [Eccl.5:19; 9:9] (it is true that for a short time and with considering the instruction: Fear God, and keep His commandments: for this is the whole duty of man. For God shall bring every work into judgement [Eccl., 8:5, 12; 12:13-14]).

Earlier in the Bible it was written that Abraam, the faithful man, was called to go for the far, elevated aim in the unknown region. God gave him the promise to make his generation to be very numerous, such as the stars in the heaven and as sand on the shore of sea. From that time the sons of the faith go, looking on the stars. But alas! How often we think only about sand, on earth dust, on the matter, forgetting the star testament!

And nobody is able to find by himself the sense of the happening without God. For God "giveth to a man that is good in his sight wisdom, and knowledge, and joy"(Eccl.2:26).

In the history of the humanity there is the curious period [5], when in the vast regions of Asia and the Mediterranean in between $\sim 6 \mathrm{sec}$. and 5 sec. before Christ the "axis" time began, i.e. the era of the known teachers- sages, or the time of the spiritual birth of the modern man. Besides the prophets of the Old Testament then appeared Buddha, Zaratustra, Confuciy and Lao-tszy (the study of Daos), Socrates and their pupils,...) when the human spirit

- began opposed himself to the nature,

- in the opposition to the naturalism and the pagan magia claimed about himself as about the infinitely valuable reality and

- in the very various forms the motion began in the direction of God, Heaven, Absolute, Way.

So, Socrates in his conversations studied the Truth not only with help self-cognition and logics (in fact, going from him - till Aristotle), but also the internal voice of God. He with dignity accepted the execution: I love you and respect you, my co-citizens, but obey more the voice of God. These words were several centures later were repeated by the apostles Peter, John and etc (Acts, 4:19; 5:29).

\section{And again return to the Bible:}

Through the prophets of the Old Testament from Moses till John Baptist God reminded to the people about Himself (with almost 5centures of the silence before John Baptist). And then also Himself appeared to the people in the Person of Jesus Christ. $\rightarrow$
And from that there is already the fourth group of the people, i.e. those which found the life, full up of the sense. They began from that, that for them the sense of human life is absurd to seek in themselves, in the dark, senseless life of the everyday experience. They found the life intelligent, or, that is the same, obtained the Alive Sense, accepted Christ and went with him.

In the Gospel, according to John the Divine revelation about the sense of the world, the sense of the being is: "In the beginning was the Word". In the original text of the Gospel according to John Word corresponds to the Greek Logos, which signifies Sense. Therefore in these verses in fact it is given the opening the mystery about the Sense. And here in the short and clear expressions we find out the following four facts.

Firstly, there is the Sense. It was already in the beginning, at all times, when God created the heaven and earth. It is the sense universal, all-explaining. All, that created God, is full of the sense. This confirmed also by the fundamental natural sciences: there is during several dozens of years known the anthropic principle, i.e. the evident tuning of many physical and cosmical constants in our universe on the appearing of a man [6].

Secondly, this Sense in His perfect state came to the earth, descended in the valley of sorrow and tears, in the world of the evil and sin. He came in the person of Jesus Nazareth. In (John, 1:14) it is written:

"And the Word was made flesh, and dwelt among us, (and we beheld his glory, the glory as of the only begotten of the Father,) full of grace and truth".

Thirdly, this Sense won the power of the dark, of the sin and of the death. In vain we would begin to seek in the Gospel the funeral speech's, sometime delivered by Christ. Meeting the funerals, He did not run from them as Buddha but ceased them, resuscitating the dead. Christ was mortified on the cross in order for to overcome the source of the evil and the primary case of the death - sin, separating the man with the source of the life, in order for to restore the unity of all and everything, in order for to heal the broken all-unity. He truly really arisen corporally and by this showed that the real Sense is eternal. "And the light shineth in darkness; and the darkness comprehended it not". He had not only wined the evil in fact (metaphysically), but $\mathrm{He}$ had also wined it in all its manifestations (historically), and in fine of everything (eschatologically). "the Lamb shall overcome them", this was said in the Revelation about the earth re, represented the power of this world (Revel., 17:14).

Fourthly, this sense is accessible to everybody, realizable to everybody, who accepts His (Christ). "But as many as received him, to them gave the power to become the sons of God, even to them that believe on his name" [John, 1:12] (i.e. secondly gave birth them from above spiritually: John, 3:6 $\rightarrow$ That which is born of the flesh is flesh; and that which is born of the Spirit is spirit'). He was and remains to be the Unique, Who could indeed say about Himself: "I am the way, the truth, and the life: no man cometh unto the Father, but by me" (John, 14:6). Namely this sense satisfies all our human demands. Everybody who knows not only the abstract thoughts on God, but also God Himself, having Him in his own personal life experience, does not torment himself by the questions on the sense of his life: God encloses in Himself the answers to all the questions, and the alive faith in Him puts the end to every subtilizing. In the light of the New Testament the life of those, who accepted Christ and was born from above (i.e. was born spiritually from God) is filled by a new sense. And here already it 
is the problem not to repair our unlucky existing aims not to try to conceive the senseless life, but to abandon it after the birth from about (from God) for the sake of the true life (with God).

When we begin in fact realize our new, true life in the personal communication with God, it becomes the aim for our will. And this aim becomes by the sense of our new personal life and our destine. And even, moreover, it becomes the aim of the history!

And in what there is the main sense of life for the man who is born from above, according to the Bible?

If the highest in a man is the spirit or the "image of God", then the sense of the human life is impossible out of God, is defined by God and must be cleared up in the interaction of a man with God [7]-in the intercourse with God, in the perception of God, in the spiritual growth and the spiritual self-realization of a man by blessing of Christ - by the blessed energy of Christ, bringing the fruits of the Saint Spirit, in the development in himself the spirit and the Divine love to the men and to the creation with the aim to bring the fruit (John,15:16). And Christ says: "Be ye therefore perfect, even as your Father which is in heaven is perfect" (Mattews, 5:48). To this perfection, the way through Christ, through accepting of His love and the answered love to him: I am the true vine, and my Father is the husbandman. Every branch in me that beareth fruit, he purgeth it, that it may bring forth more fruit. Now ye are clean through the word which I have spoken unto you. Abide in me, and I in you. As the branch cannot bear fruit of itself, except it abide in the vine; no more can ye, except ye abide in me. I am the vine, ye are the branches: He that abideth in me, and I in him, the same bringeth forth much fruit: for without me ye can do nothing. (John, 15:1-5);

"put on charity, which is the bond of perfectness"(Col.3:14). With this Christ gave us the great commission (the last verses of the Gospel according Matthew) - to us, His pupils, the Christians of all the generations, to witness about His Good Message everywhere and always - and by the direct witnesses and predications, and by their behavior and deeds, and by their love to all people.

In those, who had educated in the rejection from God, the human spirit loose the peace - and in their hearts the pain upon God appears, not always even evidently realized.

To those, who did not still accepted Christ, His sacrifice in the expiation of our sins and not repented in them, is directed the appeal of Pawl for such sense of their life (precisely, to its beginning period): "they should seek the Lord, if haply they might feel after him, and find him, though he be not far from every one of us,...For in him we live, and move, and have our being... "(from Acts,17:27-28).

And how practically we, born from above, can realize our destination? How in fact? It is clear that before all we must concretely something to make, but not sit, laying down the hands, evading from the deeds ( as "stump with eyes") and not try go away in the hermitness, in the meditation or in a certain blissful ecstasy.

Sometimes the question appears: In what is the aim of the Divine blessing?..........Before all - in the restoration of the interrelations between a man and God. And it is targeted to the more deep communications and more close relations with Him. And how does He obtain this aim in His blessing? He, as also in past, does not protect us from the accusations of the world, of the corp and of Satan, does not prevent from the displeasures (neither external, nor internal),..., from the loss of the friend, wife or work, from the death of the nearest man, from the troubles connected with the behavior of my children, and does not prevent from new temptations, problems and appeals! Namely therefore, in order to study us to hold to He the better, He deprives us step by step the self-confidence, in order we shall trust Him, shall hope to the Lord (but not in the inactivity, but in the responses to appeals).

Let us recall how God punished his men for their offences. Abraam... gave birth to Izmail, and after this he expected still 13 years till God commenced to speak with him (Genesis, 16:16-17). Moses after the murder of the Egyptia....God send him for several dozens of years in the desert in order to calm down his vanity. David committed many sins....Iona...tried to refuge from the call of God... (and he turned out womb of the whale...And now God relate to His men precisely so! $\rightarrow \rightarrow \rightarrow$

And we do often forget on the biblical principles of the education and the tempering the faith for us and on the biblical principle of the punishment for everybody: the injustice (depravity) will be punished. "whatsoever a man soweth, that shall he also reap"(Gal., 6:7) - either on the earth, or in the heavens, and not in the last turn, also for Christians. Both Christians and non-Christians will obtain by their deeds (Matthew,16:27), "For we must all appear before the judgment seat of Christ; that every one may receive the things done in his body, according to that he hath done, whether it be good or bad" (2Cor., 5:10). [+see Revel., 20: 12-13, Rom., 2: 6-11]. The gift of the justification does not defend the faithfuls from the evaluation them as the Christians! If the Christian behaved himself spoiledly, made swindles, exerted the pernicious influence on the environment, went away from the responsibility, then he will be deprived all the goods which others will obtain + (1Cor., 3: 12-15:...the fire shall try every man's work of what sort it is. If any man's work abide which he hath built thereupon, he shall receive the reward. If any man's work shall be burned, he shall suffer loss: but he himself shall be saved; yes so as by fire"). What signifies "the reward, the loss", we do not know now.

In order to consider concretely what recommendations does the Bible give both the general and the particular (personal, for any peculiar) to the born from above on the sense of his life and on the way of the realization of his destine, let us analyze the notion "the sense of the human life".

We begin once more from the repeating, and at the same time also the specification of that is Truth?

Between the various answers to this question we separate such; the truth is

- the correspondence of the knowledge to the reflected by it the reality;

- the knowledge which is true reflecting the reality (here we mark that any knowledge, including the scientific one, is based on the faith [6];

- the reality is the actual this which 'is in fact".

- In the biblical thinking the truth is everything that is from God through God and fro God. That is the truth is comprehended in the right relations with God and the nearests, it is "the faith" and "the faithfulness" (to the Covenant), it is the source of the real human freedom, obtained in the results of the serious spiritual efforts.

These definitions do not contradict each other and partially mutually intersect and mutually add each other. (By the way, in Russian, English and Italian the words true and faithful in a certain sense one can consider by synonyms). The truth can be polyhedral and 
Page 5 of 6

paradoxical (it is known in science, and in philosophy, and in theology, and in the Bible: Jesus Christ effectively used the paradoxes and antinomies for the delivery of the deep truths (the firsts will be the lasts, and the lasts will be the firsts; who from you is the greater, be as the lesser; who is commanding, be as an employee; the force of God is effected in the infirm).

There are the truths which can endure any critical checks, controls, verifications. They are named by absolute (more correctly, there are the fragments of the absolute truth). They are conceivable, and sometimes by a mystery way (especially those which are revelated by God through His Writing - Bible). If the absolute thruths were not exist and/or were not conceivable, then we would not have any base to say about no thruth, including the relative one. Relative truths exist only therefore and insomuch, because and inasmuch the absolute truths exist!

Everyone can find in the Bible the answer on the question about the sense of the human life (also about the truth and about the destination) and, moreover, there is much written in the Bible also about the obstacles to the conceiving the sense and the destination of our life.

In the Bible everyone can find the answer about the sense of the human life (and on the truth and on the destination) and, moreover, much is spoken on the overcoming to the comprehending of the sense and the destination of our life.

Firstly consider what the Bible says on the truth.

Jesus Christ said on Himself: "I am the way, the truth, and the life: no man cometh unto the Father, but by me"(John, 14:6). And He also predicates us on the search of the truth and the personal destination:

Blessed are the meek: for they shall be comforted (Matthew, 5:6).

Ask, and it shall be given to you; seek, and ye shall find; knock, and it shall be opened unto you;

For every one that asketh receiveth; and he that seeketh findeth; and to him that knocketh it shall be opened (Matthew, 7:7-8; Luca, 11:9-10).

And that, who did un-sufficiently thirst the truth and did not seek the sense of his life or did not seek them in Christ, then he himself carries the responsibility for that, that he did not find the truth and the destination of his personal life!

From the New Testament we know also that J. Christ in all his predications, parables and expressions never does not exclude our mind, on the contrary, He cleans our mind from the errors, mistakes and illusions. And $\mathrm{He}$ cleans our will from the egoism $\rightarrow$ i.e. from the sin (because errors, mistakes, illusions and egoism, distorting the truth, are caused by the sin fall). I.e. He enlightens, renovates and consecrates our mind.

\section{And further:}

John, 8: $32 \rightarrow$ And ye shall know the truth, and the truth shall make you free.

James, 1: $25 \rightarrow$ But whoso looketh into the perfect law of liberty, and continueth therein, he being not a forgetful hearer, but a doer of the work, this man shall be blessed in his deed.-

(firstly) it is the liberty from the slavery of the sin; (secondly) it is the given to everyone from us by God the liberty of the choice of liberty with the taking of the decisions in the concrete situations;

(thirdly) we always need the larger perceiving of the Truth (in order finally to perceive it to the end)-namely for the deed by the will of God: the decision of any problem, the healing of the personal pain, the taking of any decision.

\section{Conclusion}

And now - what the Bible says on the aim and the destine of our personal life.

- The every Christian, born from above, with all his behavior and gifts (but not only by his words) it is natural and supernatural to be the light to the world and the sale for the earth (so Christ says on the predestination of everybody from the men, born from above!).

- And for this the gifts of the Saint Spirit help to us $\rightarrow$

- The spiritual gift is the peculiar ability which is given by the Saint Spirit to everybody in addition to the nature abilities. At the difference from the natural abilities, the gifts are given for the needs of the Church, firstly, in the Christian commune for the help to each other and for the appeal for the unbelieving persons to Christ.

...The gifts and the calling of God are without repentance (Rom., 11: 29). Without the functioning of the gifts there is no the life of the church! And the service of the church is spreaded not only for its members, but also onto the all the world - both for the people and the enterprises of the external world. And in this world the church must live by its life, use all their spiritual gifts and appeal to Christ.

\section{With this the gifts are individual:}

But the manifestation of the Spirit is given to every man to profit withal (1 Cor., 12:7). And the knowledge of his spiritual gifts helps to the every born from above:

- to find the will of God namely in his life,

- to come off the too large involvement in those works which are not connected with our gifts ( and before all from the false gifts which appear not by the will of God but due to our egoistic tends). It is useful to remember the parabola on the talents in Matthew, 25:21, 23: how Christ negatively relates to bury own talent (both the natural and the spiritual gifts) into the earth.

- Every spiritually mature Christian realizes of the continuous deepening into the understanding of himself, his life through the Bible. 1Timothy, 4:16 $\rightarrow$ Take heed unto thyself, and unto the doctrine; continue in them: for in doing this thou shalt both save thyself, and them that hear thee. Why? $\rightarrow$

We know that after the birth from above we became the participant of the Divine nature. And simultaneously we know that in every of us there is also another nature- "old, sinful nature", the sin which is living inside us. It is not very pleasant this impure, disgustful reality.

But, as the Bible says, we must the better known ourselves. The monster of the old nature inside us is opposed to the work of God with the help of the deceit of our mind. The deceit masks the harmful for us in that seems to us the desirable and pleasant (as the fisherman-angler masks the hook by the bait-lure). The deceit hides from our mind those sorrowful consequences which we must analyze before the peck, 
nibble, bite the lure and finally to be caught on the hook. Our old nature is the wily cheat, gloomy, guileful, seductive, and, if it is necessary, patient and persistent. It well knows all our weaknesses...

Some Christians, even recognizing evidently their complete dependency from Christ, neglect the importance of the balanced seeing of our nature and fall into one from two extremities. If we are focused only on our new resources through the New Testament without the necessary considering our fallen, earth nature, then in the result we shall inspire by the unjustified optimism. Then we shall abstract from our human debility and from the un-removable reality of the struggle $\nabla$ and in the result we can unnoticeably be caught onto the hidden hook ... If we shall focus only on our fallen nature without necessary considering of our new recourses, then this will bring to the unjustified surrender of our positions, to the concessions and compromises with the fallen nature that always will finish by the spiritual downfall, the defeat. We shall not able to use our Divine resources and we shall remain of the un-justify low level of our spirituality.

- Now we present some examples of the typical conflicts for the modern society $\rightarrow$

The modern society (including the Ukraine), as never in the past, is oriented for the success of any activity but the success+ the evaluation of the success does not usually depend from the worldview, the religion faith, the moral orientations but only from the ability to "enter" in the existing mechanisms. This is the strong challenge to the Divine Being from the side of the modern as if self-sufficient secular world! To this challenge had been proceeded and promoted the past challenges - of Protagor in the antiquity, of Feierbach, Marx, Darwin, Freid, Nizsce, B.Rassel and many others in 19-20 cc.

And in the personal life of all people (and for every man the life is own, individual, including the Christians) $\rightarrow$

From one side, the Bible appeals to us wisely to direct and to highly esteem time:

[(Psalms, 90:12): "So teach us to number our days, that we may apply our hearts unto wisdom" (Ephes., 5:15-17): "See then that ye walk circumspectly, as fools, but as wise'] and in many places very positively marks the love, the matrimony, the family, the creative labor, the wealth, the health (and their role in the conceiving of the human life).

But, from other side, the limited homo-centric ("intoxicating", fussy,...) enthusiasm of the labor, the salary, the professional growth, the family, the strengthening of the health, the healing, ... [i.e. all this, which is not the sense of life but only the conditions of the revealing of the personality, - general and individual] or the limited homo- egocentric immersion in the problems of the solitude or of the unfortunate matrimony in the personal life, or unfortunate choice of the profession,..., involving into the conflicts,..., and then the sufferings and vanities in our temporal world, not only distract from the search of the sense of life of non-Christians, but also distract also the Christians from the thoughts on the sense and on the predestination of their personal life, on the eternal consequences of their personal earth decisions which are not of the mode in the modern secular world. And they forget the words of Christ "shall not live by bread alone, but every word of God"(Luke, 4:4) [8].

Sometimes even the sincere Christians forget that we (born from above) live really in two parallel worlds (in usual, visible, natural, temporal and also in the unusual, invisible, spiritual, supernatural, and eternal) and that without such reality there is no sense of our personal life [9].

And in all times only the Word of God gives the compass to us which indicates to the will of God and for the God's presence in any context: $\rightarrow$

When men work for the justice, freedom, mutual understanding, reconciliation, unity and truth in the spirit of the love-agape and witness on the Good Message, they work as the collaborators of God. But when the men are enslaved, the enmity is inflames, the mutual responsibility is denied in the spirit of the homo-egocentrism and the lie is wedged in, we see the work of the forces, opposing to the incoming of the God's kingdom.

The talks on the necessity to "remain everything in the hands of God" are in fact the going away from the responsibility and from the Good Message. God cannot be identified with the historical process: it realized by the opposed to each other sinful men and godly men!

\section{References}

1. Pirogov NI (1910) The questions of life, Works. Kiev 1: 37-72.

2. Camu A (2007) Myth about Sizife, Moscow, "Alphabet-Classica".

3. Shopengayer A (1966) The world as a will and representation.

4. Matzinkovsky VF (1996) Sense of life, Novosibirsk: POSOH.

5. Men A (1995) The world spiritual culture, Lectures and conversations.

6. Olkhovsky VS (1998) How does science correlate with the Christianity, atheistic scientism and mysticism of "New Era". Volume Man and the Christan worldview Simferopol, 3: 244-251.

7. Olkhovsky VS (1998) On knowledge, truth and faith, in volume Man and the Christan worldview. Simferopol 3: 244-251.

8. Fioletov NN (2000) Sketches of the Christian apologetics, Klin, fond "The Christian life".

9. Trubetskoy EN (1994) Sense of life. Moscow. 